\title{
A Change in Tourism Management: New Normal Era in Riau Islands Province
}

\author{
Kismartini ${ }^{1}$, Hartuti Purnaweni ${ }^{2}$, Titik Djumiarti ${ }^{3}$, Nurul Khotimah ${ }^{4}$ \\ $\left\{\right.$ kismartini@live.undip.ac.id $\left.{ }^{1}\right\}$ \\ Universitas Diponegoro, Indonesia ${ }^{1,2,3,4}$
}

\begin{abstract}
The impact of the Covid-19 pandemic has significantly been affected by various development sectors, and tourism was the biggest sector had dropped by Covid19. Change Management in tourism is needed for facing Covid-19 era and afterwards, therefore this study aims to analyze changes in tourism management in the Riau Islands Province. Phenomenology qualitative research approach used in this research, data analysis techniques with interactive models. The result shows the Riau Islands Province Government had begun to make changes in tourism management through establishing a sense of urgency, namely delivering the belief that the tourism sector must immediately rise considering that the economic wheels in the Riau Islands are greatly supported by the tourism sector. The Riau provincial government has also done creating the guiding coalition, which is an effort to analyze the Batam Tourism Polytechnic (BTP) in the management of the tourism sector. Then the last one is developing a vision strategy, which is related to continuing to promote tourism by making changes to tourist targets which are the Riau Islands Province during the pandemic. The recommendation from the researchers is the need to develop a vision and strategy in a systematic and structured manner by involving stakeholders with interest in development in the Riau Islands Province.
\end{abstract}

Keywords: Change Management, Tourism Management, Establishing a Sense of Urgency, Creating the Guiding Coalition

\section{Introduction}

The Covid-19 outbreak has hit almost countries in the world. The pandemic first appearance since the end of 2019 in Wuhan, China. In addition, Covid-19 also effected almost in all-region. The Covid-19 pandemic spreads quickly and transmitted into each other. Various countries have implemented lockdown policies (regional quarantine to limit the spread of the virus, however shifting human behaviour is not easy like. Indonesia has modified by issuing a Large-Scale Social Restriction (PSBB) policy in an effort to reduce the outbreak initiated by the Ministry of Health [1].

The outbreak of Coronavirus made a huge impairment in many sectoral, not only individual losses but also any potential business was badly affected. The tourism sector was dropped due to Covid-19, it might be seen by a slow response among domestic, and international tourism [2]. Riau Island Province is one of a province which relies on tourism as the main sector to boost its regional economy. Beside of that Riau Island Province also the third contributor to state revenue after Jakarta and Bali from the tourism sector [3]. 
Prior to the pandemic, tourists visiting the Riau Islands were dominated by foreign tourists it was caused by strategic location and closely with Malaysia and Singapore border. Moreover, pandemic had the biggest multifactor challenge that makes tourist visits dramatically decreased. It was due to many countries-imposed travel restrictions to prevent the spread of the Covid-19 virus. Moreover, tourists are also afraid related with health and safety. The numbers of declining tourists were released by the Ministry of Tourism and Creative Economy as a follow:

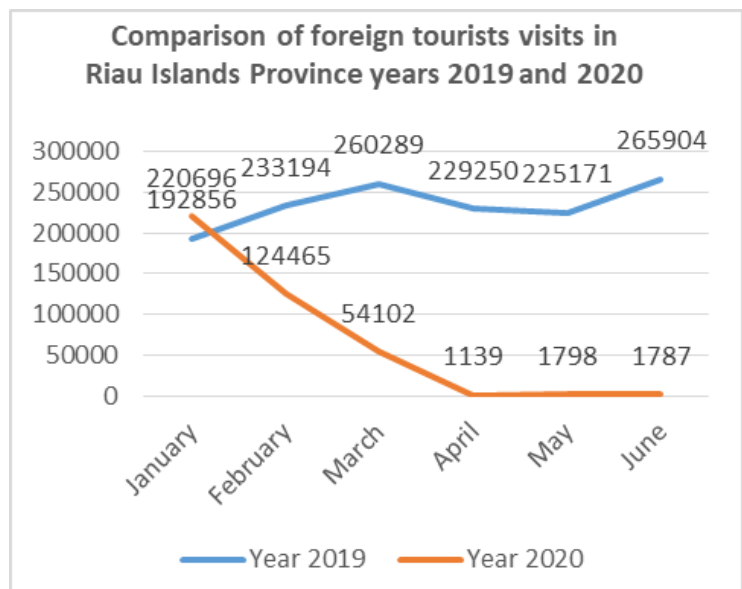

Fig. 1. Comparison in years 2019 and 2020 foreign tourist visits in Riau Islands Province Sources: Ministry of Tourism and Creative Economy (Processed data)

According to data published by the Ministry of Tourism and Creative Economy, it shows that tourist visits in January to June 2020 periods had decreased significantly. It was dropped almost $99 \%$ compared by years of 2019 . Therefore the declining number of tourist have a direct impact on various other supporting sectors such as hotels, restaurants, travel agents, and SMEs [4]. Even though this trend also had an impact on the hotel occupancy rate, which in 2019 was around $50.20 \%$, whereas in 2020 only $10 \%-15 \%$. The weakening of the tourism sector also resulted in a decline in the economic growth of the Riau Island Province in the second quarter, it was declined at $6.66 \%$, as the lowest income on Sumatera and even influenced in national economic growth around 5\% [5].

The new strategies must be implemented to facing a multiplayer impact, especially in the economic sector, as Pamungkas said that new normal is a new approach to the provision of service in society. Additionally, the New Normal method was necessary to be implemented to tackle economic issues while Covid-19 has been not finished yet [6]. The Provincial Government of the Riau Islands Province is demanded to shift up in tourism management in an uncertainty condition. The management of tourism in the new normal era must guarantee the security and safety of tourists when travelling in the Riau Islands Province.

According to Graetz et al., change does not have a specific definition that could be used as a concept of change, but change is and identical to innovation, improvement, evolution, and adjustment, etc. The word of change is defined as where the word is used to [7]. In this unpredictable course, change related to adjustment to tourism management in the new normal era need to be made so that tourism actors can survive and coming back amid the Covid-19 to wake up from "economic coma". 
Change Management is one of the steps in a public organization which is a process to change the process and procedures of the public bureaucracy, and the attitudes and behaviour of bureaucrats to achieve bureaucratic effectiveness and national development goals or it can be said that resource management in order to achieve organizational goals with better performance. Therefore, change management will be a basic guide for the organization in undergoing a transition period from the current state to the expected condition. Change management is one of the factors in the successful implementation of bureaucratic reform effectively and efficiently [8].

John Cotter 919960 suggests eight steps of change as a reference for carrying out the stages of change from current conditions to expected conditions.

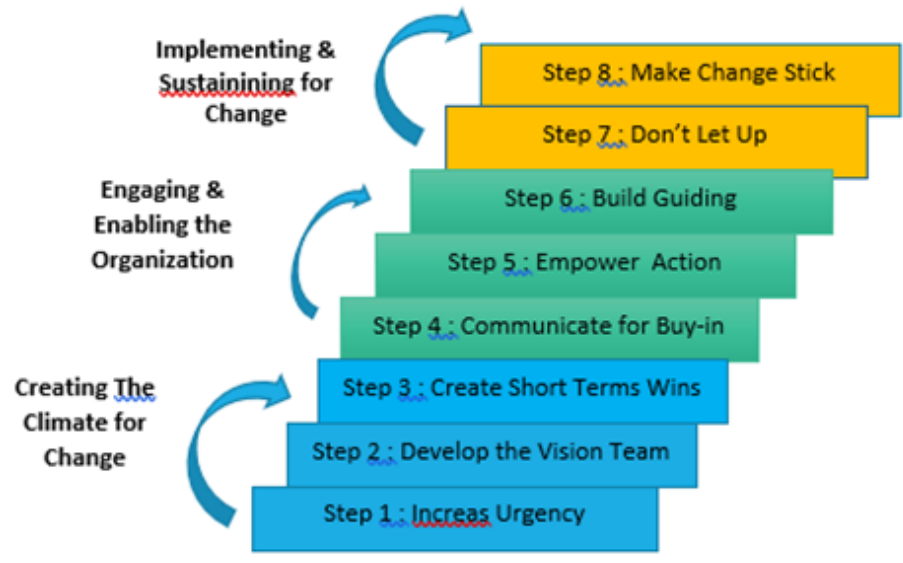

Fig. 2. Change model according to Jhon Kotter Sources: Management Study Guide.

The eight steps of change management brought by Jhon Kotter explained the stages in making changes. In these steps are divided into three phases in a management change, the first phase is creating the climate change, which is related to the analysis of how important it is to make changes in management, then the second is engaging and enabling the organization, which related to communication and coordination between stakeholders to make changes and the last is implementation and sustaining for change related to support in implementing management changes.

Change Management is a method of adaptation in managing and achieving goals. Change management is seen to be carried out in the new normal conditions as considering there was an instability condition, as proposed by Kotter, it is appropriate to analyze changes that are used by Riau Islands Government in managing change management tourism in the new normal condition amid Covid-19 pandemic.

\section{Methodology}

This article uses a descriptive qualitative approach. A method for understanding deeply the meaning of individuals or groups of people who regard something as a social problem or a 
human phenomenon. Another opinion states that descriptive qualitative research is research that aims to describe a particular social phenomenon [9].

This research focuses on change management of tourism in the face of the Covid-19 pandemic outbreak in Riau Islands Province. Primary and secondary data are used in this research, through interview techniques, observation and documentary studies. Furthermore the informant are including Regional Development Planning Agency and Tourism and Culture Office Riau Islands Province to support this research.

\section{Discussion}

The negative impact of the Covid-19 pandemic on the tourism industry in the Riau Islands Province is greatly felt by the local government, tourism activities and the community. The impacts that occur include a significant decline in the hotel and lodging industry, transportation, performances, and other sectors such as art and cultural actors, and also small and medium enterprises sector.

The results showed that The Riau Islands provincial government began to respond to the various impacts of the Covid-19 pandemic, namely by Implementing Change Management Tourism. It was involving several steps as stated by Kotler, namely establishing a sense of urgency and creating the guiding coalition, developing a vision and strategy, communicating the change vision, empowering employees for broad-based action and generating short term wins, etc. This research has found three steps for The Change Management that recently begun in Riau Islands Province, namely establishing a sense of urgency, creating the guiding coalition and developing a vision and strategy.

\subsection{Establishing a Sense of Urgency}

At this stage, identification and study of internal and external situations faced and discussing crises or potential crises or big opportunities is carried out so that it requires change. The Riau Islands government recognizes the need for changes to the current situation. Absolute change must be undertaken by every individual in an organization, both government and non-government organizations.

The awareness component includes understanding the objectives of the empowerment program regarding the benefits that will be obtained from change, the risk of rejection of change, influencing parties, which aspects need to be changed, change procedures, etc. To make it easier to build public awareness for change is to convey clear information about the changes that will be made. This can be done by using information media (channels), forming a dialogue forum that takes time to build awareness. The desire (desire) to participate in and support change must be owned by the target of the empowerment program, where the will vary. In the target community, there are groups who have a desire to change, there are those who are indifferent to change and there are also groups who are resistant to change. The desire to change can be caused by the belief that the new condition is better than the present, the expansion of opportunities to develop one's potential, the feeling of belonging, the discomfort of the existing condition, etc. Knowledge (knowledge) refers to the learning process which includes learning about change and information about how to change. The target group needs to understand what will be different and stay the same as changes take place. The knowledge in question is about what the empowerment process is, what the procedure is, what skills are needed, etc., which ultimately forms. 
The pandemic condition which weakens the tourism sector as it is currently being responded quickly by all stakeholders in the Riau Islands. The Riau Islands Provincial Government supports all forms of efforts to revive the tourism sector in the Riau Islands, this is because Riau Islands is the second destination for foreign tourists after Bali [10].

The Head of the Riau Islands Province Tourism Office said that until May 2020 the pandemic had caused 14,000 tourism workers to experience layoffs (PHK), was laid off, and received a wage discount. Of course, this condition will have an economic impact on all tourism workers [11].

The impact of a pandemic has become increasingly complex, causing drastic changes. The tourism sector as one of the leading sectors in the Riau Islands Province must immediately improve and rise to make changes in management considering that in the next five years, tourism will become a national priority and several districts/cities in the Riau Islands Province have become national strategic areas such as Batam City and Bintan Regency. Tourism management must immediately make changes by adapting to the current pandemic conditions [12].

\subsection{Creating the Guiding Coalition}

Create a working group as a team to lead a change that can be used by cross-functional and cross-level. This work is expected to set up a policy and their results will guide the course of the change process.

According to Sutrisno [13] Golf Tournament is the first event started amid Covid-19 since Batam Mayor has given relaxation for the tourism sector on $15^{\text {th }}$ July guided by health safety protocol.

Batam Tourism Polytechnic (BTP), is one of the best private polytechnics school in tourism sector located in Batam, Riau Islands Province provide an overview of three tourism trend's, namely:

\subsubsection{Stricter Travel Procedure}

Health protocols in the various technic of transportation are expected to continue to maintain the comfort of tourists. The example is the procedure for travelling by plane. Currently, the Government of Indonesia giving a license for travelling by a plane which requires a free Covid-19 certificate even though it was enforced during the Large-Scale Social Restriction (PSBB).

That new procedure may become a mandatory requirement in the future. Considering the importance of passenger health documents, airports are required to participate in developing their services by providing health checks and mass testing, especially at airports where a biggest spot of tourist's hub. This procedure also can be applied to any mode of transportation like bus, train, or ship.

\subsubsection{Bringing Cleaning Equipment is a Must}

Hygiene living behaviour is becoming a new habit that has to be practiced in travelling. Thus, cleaning supplies such hand soap, hand sanitizer, tissue, and masks become important entities that must be brought yet. In responding to these needs, tourist destinations or public areas must care and always implement cleanliness and physical distancing procedures. This strict and continuous procedure should be a priority for the entire tourism industry. This is 
because the cleanliness aspect will be one of the essential considerations when visitors choose tourist attractions, such as restaurants and hotels. Therefore, the business industry must pay attention to and campaign for hygiene standards that are applied so as to increase business credibility in the eyes of tourists.

\subsubsection{Touch Less Tourism}

One of the changes that are perhaps the most visible is the shift in travel patterns to be touch less, from the airport to check-in at hotels. The reason is, even though destinations and public places have strict hygiene protocols, there is still a high risk of infection. They were starting from checking travel documents (passports and boarding passes), touching during check-in, security, and others. Therefore, future use of technology will become the new norm where tourists do not need to touch public areas, thereby reducing the possibility of virus transmission. This technology can be in the form of touch less document scanning, voice command, or motion detection sensors. I Gusti Ngurah Rai Bali Airport have implemented a technology system in the form of the use of an Online Customer Service system, boarding pass scanners, and Digital Meeting Points (DMP) to reduce physical interaction between people at the terminal.

\subsection{Developing a Vision and Strategy}

In developing a vision and strategy stage, it is related to a strategic vision for making changes. Vision goals to deliver change efforts and develop strategic initiatives to achieve this vision [15].

The Riau Islands Provincial Tourism Office is supported by the Regional Tourism Promotion Board (BPPD) determined to continue to promote tourism while pandemic and currently being strengthened by the implementation of the new normal era. Beside of that the government focused on domestic tourists so the economy will be growth. Hence the government of Riau Islands Province has not relied on foreign tourists but put concern on domestic tourists as the main target [16].

Instead of preparing several alternatives to boost tourist's visits, the government also introduce "BISA" program (Clean, Beautiful, Healthy, and Safe) and facilitated by the Ministry of Tourism and Creative Economy. This program has the campaign to improve awareness of society to travel in the new normal era of the Covid-19 pandemic [17].

\section{Conclusion}

In conclusion, we can be said The Riau Islands Provincial Government has implemented an initial phase in changing tourism management based on the change model proposed by Jhon Kotter, namely the phase of creating the climate for change which includes establishing a sense of urgency, by determining the essential of change management tourism, which encourages all stakeholders to support all that is needed for transform management and continue to convince stakeholders that changes in tourism management are needed.

The government fully supports all actions taken to revive the tourism sector as one of the economic foundations of the Riau Islands. In addition, the Riau Islands Government also created the guiding coalition, namely cooperation related to things that need to be done to provide safe and comfortable services so as to convince both domestic and foreign tourists to 
travel to the Riau Islands Province. Then the last one is developing a vision and strategy related to a change in tourism management vision and determining strategic steps to achieve this vision.

\section{References}

[1] M. Muhyiddin, "Covid-19, New Normal, dan Perencanaan Pembangunan di Indonesia," Indones. J. Dev. Plan., vol. 4, no. 2, pp. 240-252, 2020.

[2] W. Hadiwardoyo, "Kerugian Ekonomi Nasional Akibat Pandemi Covid-19," BASKARA J. Bus. Entrep., vol. 2, no. 2, pp. 83-92, 2020.

[3] M. Indonesia, "Pariwisata Bakal Jadi Fokus Kepri,” Media Indonesia,” 2020. .

[4] Kemenparekraf.go.id, "Data Kunjungan Wisatawan Mancanegara Bulanan Tahun 2020," 2020.

[5] B. Bani, "Ekonomi Kepri Turun 6.66 Persen, Terendah se-Sumatra. sumatra," Bisnis.com.2020.

[6] A. Habibi, "Normal Baru Pasca Covid-19," 'ADALAH, vol. 4, no. 1, 2020.

[7] A. I. Akinbode and S. R. A. Al Shuhumi, "Change Management Process and Leadership Styles," PEOPLE Int. J. Soc. Sci., vol. 4, no. 2, 2018.

[8] M. S. Guide, "Kotter's 8 Step Model of Change," Managementstudyguide.com. .

[9] J. W. Creswell, Research Design Qualitative, Quantitative, and Mixed Method Approaches, Second Edi. 2017.

[10] H. Kepri, ““'Sektor Wisata Kepri Aktifkan Kembali Sijori'.,” humas.kepriprov.go.id.2020. .

[11] N. Azizah, "14.000 Pekerja Wisata Kepulauan Riau Terdampak Covid-19"," Republika.co.id.2020. .

[12] I. D. G. Sugihamretha, "Respon Kebijakan: Mitigasi Dampak Wabah Covid-19 Pada Sektor Pariwisata," Indones. J. Dev. Plan., vol. 4, no. 2, pp. 191-206, 2020.

[13] C. Sutrisno, "Partisipasi Warga Negara Dalam Pilkada," JPK (Jurnal Pancasila dan Kewarganegaraan), vol. 2, no. 2, pp. 36-48, 2017.

[14] I. Ma'ruf., "Pariwiwsata Batam Bersiap Bangkit Usai Terpukul Covid-19," Inews.id. 2020 .

[15] F. Ikhram, "Pengembangan Manajemen Perubahan dalam Upaya Meningkatkan Efektivitas Penerapan Enterprise Resource Planning,” J. Ilm. Magister Adm., vol. 12, no. 1, 2019.

[16] A. Lazuardi, "Saatnya Kepri Memanjakan Wisatawan Domestik, bgaimana Caranya?," Kompas.com.2020. .

[17] V. Dimyati, "Sambut Wisatawan Saat New Normal, Kepulauan Riau Bersih-Bersih Pantai," Inews.id. 2020. 